\title{
Tumor Findings Result Category
}

National Cancer Institute

\section{Source}

National Cancer Institute. Tumor Findings Result Category. NCI Thesaurus. Code

C119937.

A classification of a tumor findings result. 